\title{
Essential oils of Cunila galioides and Origanum majorana as anesthetics for Rhamdia quelen: efficacy and effects on ventilation and ionoregulation
}

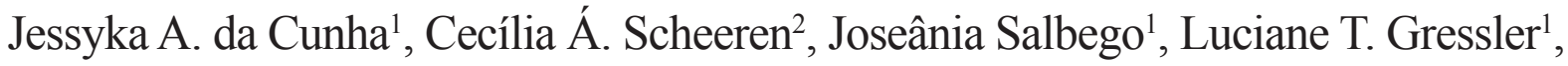 \\ Laurício M. Madaloz ${ }^{3}$, Guerino Bandeira Junior ${ }^{2}$, Adriane E. Bianchini ${ }^{1}$, Carlos G. Pinheiro ${ }^{4}$, \\ Sérgio A. L. Bordignon ${ }^{5}$, Berta M. Heinzmann ${ }^{1,6}$ and Bernardo Baldisserotto ${ }^{1,2}$
}

This study evaluated anesthetic efficacy and possible effects of the essential oils (EOs) of Cunila galioides (EOC) and Origanum majorana (EOO) on ventilatory rate (VR) and ionoregulation in Rhamdia quelen. In the anesthesia assessments, 50, 100, 200 and $300 \mu \mathrm{L} \mathrm{L}^{-1} \mathrm{EOC}$ and 50, 100, 200, 300, 400 and $500 \mu \mathrm{L} \mathrm{L}^{-1} \mathrm{EOO}$ were tested, and time for induction to sedation and anesthesia stages, as well as recovery, were taken. A second trial employed lower concentrations of both EOs, 10, 25, 50 and $100 \mu \mathrm{L} \mathrm{L}^{-1}$, in order to verify VR and $\mathrm{Na}^{+}, \mathrm{K}^{+}$and $\mathrm{Cl}^{-}$whole body net fluxes. Sedation was achieved with both oils at 100 $\mu \mathrm{L} \mathrm{L}^{-1}$, and anesthesia at $\geq 200 \mu \mathrm{L} \mathrm{L}^{-1}$. There was no significant difference between control and EO-treated groups regarding VR, but all fish subjected to $100 \mu \mathrm{L} \mathrm{L}^{-1} \mathrm{EOC}$ died within $2 \mathrm{~h}$ of exposure. Overall, ionic loss declined in the presence of the EOs. The EOC at $200-300 \mu \mathrm{L} \mathrm{L}^{-1}$ and EOO at $400-500 \mu \mathrm{L} \mathrm{L}^{-1}$ present the potential to promote fast anesthesia in $R$. quelen.

Keywords: Ionoregulatory balance, Marjoram, Pennyroyal, Silver catfish, Ventilatory rate.

No presente estudo foi avaliada a eficácia da anestesia e possíveis efeitos dos óleos essenciais (EOs) de Cunila galioides (EOC) e Origanum majorana (EOO) sobre a taxa ventilatória (VR) e regulação iônica em Rhamdia quelen. Nas avaliações de anestesia, as concentrações de 50, 100, 200 e $300 \mu \mathrm{L} \mathrm{L}^{-1}$ EOC e 50, 100, 200, 300, 400 e $500 \mu \mathrm{L} \mathrm{L}^{-1}$ EOO foram testadas, e os tempos para a indução às fases de sedação e de anestesia, assim como recuperação, foram mensurados. Um segundo ensaio empregou concentrações mais baixas de ambos EOs: 10,25, 50 e $100 \mu \mathrm{L} \mathrm{L}^{-1}$ a fim de verificar a VR e o fluxo líquido corporal dos íons $\mathrm{Na}^{+}, \mathrm{K}^{+}$and $\mathrm{Cl}^{-}$. A sedação foi alcançada para ambos os óleos em $100 \mu \mathrm{L} \mathrm{L}^{-1}$, e a anestesia em concentrações $\geq 200 \mu \mathrm{L} \mathrm{L}^{-1}$. Não houve diferença significativa entre o controle e grupos tratados com EOs em relação a VR, mas todos os peixes submetidos a $100 \mu \mathrm{L} \mathrm{L}^{-1}$ do EOC morreram dentro de $2 \mathrm{~h}$ de exposição. No geral, a perda iônica declinou na presença dos EOs. O EOC em 200 - $300 \mu \mathrm{L} \mathrm{L}^{-1}$ e o EOO em 400 - $500 \mu \mathrm{L} \mathrm{L}^{-1}$ apresentam potencial para anestesia rápida em $R$. quelen.

Palavras-chave: Balanço ionoregulatório, Jundiá, Manjerona, Poejo do campo, Taxa ventilatória.

\section{Introduction}

Brazil is currently the country with the biggest potential for farmed fish production due to a favorable climate and a hydrographic network that holds about $12 \%$ of the planet's fresh water (Brasil, 2014a). In 2013, Rio Grande do Sul state produced 17 thousand tons of freshwater fish, which represented $4.33 \%$ of the national volume for that year (Brasil, 2014b). Rhamdia quelen is widely spread in southern Brazil, Argentina and Uruguay, and its economic relevance is steadily increasing. This species tolerates well the cold winter of the region and presents a high reproductive rate and a rapid weight gain during the warmer months, even when raised in artificial tanks or in polyculture together with other fish species (Gomes et al., 2000; Baldisserotto, 2009).

${ }^{1}$ Programa de Pós-Graduação em Farmacologia, Universidade Federal de Santa Maria (UFSM), Av. Roraima, 1000, Prédio 21, 97105900 Santa Maria, RS, Brazil. (JAC) jessyka.arruda.c@hotmail.com; (JS) josalbego2004@yahoo.com.br; (LTG) lutgressler@hotmail.com; (AEB) adriane_erbice@hotmail.com; (BB) bbaldisserotto@hotmail.com (corresponding author)

${ }^{2}$ Departamento de Fisiologia e Farmacologia, Universidade Federal de Santa Maria (UFSM), Av. Roraima, 1000, Prédio 21, 97105-900 Santa Maria, RS, Brazil. (CAS) ceciliascheeren@hotmail.com

${ }^{3}$ Agricultural engineer, Irrigatec ${ }^{\circledR}$, 99680-000 Constantina, RS, Brazil. lauricio_madaloz@hotmail.com

${ }^{4}$ Programa de Pós-Graduação em Engenharia Florestal, UFSM, Santa Maria, RS, Brazil. carlosgp07@yahoo.com.br

${ }^{5}$ Mestrado em Avaliação de Impacto Ambiental, Centro Universitário La Salle, Av. Victor Barreto, 2288, 92010-000 Canoas, RS, Brazil. bordignon@ibest.com.br

${ }^{6}$ Departamento de Farmácia Industrial, UFSM, Av. Roraima, 1000, Prédio 44, 97105-900 Santa Maria, RS, Brazil. berta.heinzmann@hotmail.com 
Boost in aquaculture production and economic importance of $R$. quelen should run parallel with technological improvements in order to preserve life quality of the farmed fish. Among the many factors which may interfere negatively in the animal's living conditions and their performance are procedures such as capture, blood collection, tank transfer, confinement and transport, which are associated with stress (Barton et al., 1980; Salbego et al., 2015). In this context, the use of anesthetics as MS-222 and metomidate during fish handling represents an alternative to minimize such inconveniences. Nevertheless, these synthetic drugs may act as chemical stressors and trigger undesirable side effects as weight loss, acidosis and osmotic stress as a result of the inadequate blood-water gas and ion exchange (Sladky et al., 2001; Bolasina, 2006; Zahl et al., 2012). Alternatively, a growing number of studies employing plant-derived compounds have been produced, including investigations with essential oils (EOs) of Lippia alba (Cunha et al., 2010; Parodi et al., 2014; Toni et al., 2014), Ocotea acutifolia (Silva et al., 2013b), Nectandra megapotamica (Tondolo et al., 2013), Aloysia triphylla (Gressler et al., 2014; Parodi et al., 2014; Zeppenfeld et al., 2014) and Hesperozygis ringens (Silva et al., 2013b; Toni et al., 2014). These natural EOs have been proven effective for sedation and anesthesia of fish with advantages over synthetic alternatives, e.g., lower cost and higher security (Silva et al., 2013b; Tondolo et al., 2013). However, natural products may also trigger some stressful effects and induce physiological changes (Benovit et al., 2012; Gressler et al., 2014).

Among the plants producing EOs is Cunila galioides, a native species which grows wildly in moist environments, especially in the northeastern mountains of Rio Grande do Sul, Santa Catarina and Paraná states (southern Brazil). Medicinal and aromatic properties of the essential oil (EO) of $C$. galioides (EOC), as well as the good extraction yield, suggest the possibility of using this plant in herbal treatments (Mossi et al., 2012). Trans- $p$-2,8-menthadiene1 -ol, 1,3,8-menthatriene, trans- $\beta$-ocimene, endoborneol, neral, and geranial are some of the constituents which may be found in the EOC (Echeverrigaray et al., 2003). Origanum majorana is another species rich in EO, which is well adapted in Brazil and has been popularly used for treating asthma, headache, rheumatism and central nervous system (CNS) disorders due to its anti-epileptic and sedative effects (Jun et al., 2001; Deshmane et al., 2007). Literature reports cite myrcene, $\gamma$-terpinene, $\alpha$-terpinene, $p$-cymene, borneol, thymol, carvacrol, $\beta$-caryophyllene, limonene, $\alpha$-pinene, $\beta$-pinene, linalool and sabinene as some of the compounds in the EO of $O$. marjorana (EOO) (Tserennadmid et al., 2010; Orhan et al., 2012; Fratini et al., 2014).

Potential of $C$. galioides and $O$. marjorana for fish anesthesia has not yet been investigated. Thus, the present study aimed to evaluate the anesthetic efficacy of the EOC and the EOO in $R$. quelen, as well as their effects on fish ventilation and ionoregulation after being subjected to capture, transfer and confinement.

\section{Material and Methods}

Plant material and essential oils analysis. Flowering aerial parts of $C$. galioides were harvested in March 2015 (end of summer) in Santo Antônio da Patrulha, Rio Grande do Sul State (RS), southern Brazil. A voucher specimen was deposited in the herbarium of the Departamento de Biologia, Universidade Federal de Santa Maria (SMDB no. 15441). EOC was extracted by hydrodistillation using a Clevenger type apparatus for $3 \mathrm{~h}$ (Council of Europe, 2007) and stored at $-4^{\circ} \mathrm{C}$ in amber glass bottles. EOO was commercially obtained from Agribusiness São Caetano Ltda (Vimontti ${ }^{\circledR}$, Santa Maria, RS, Brazil).

Analysis of the EOs chemical composition was performed by GC-MS TIC as described by Silva et al. (2012). The constituents of the EOs samples were identified by comparing their mass spectra to a mass spectrum library (Adams, 2001; Nist, 2010).

Fish and water quality. Juvenile $R$. quelen (voucher UFRGS 20412), body net weight $10.84 \pm 0.16 \mathrm{~g}$ and total length $11.3 \pm 0.2 \mathrm{~cm}$,were transferred from a local fish culture to the Fish Physiology Laboratory (Universidade Federal de Santa Maria - UFSM), where they were acclimated for 7 days in $250 \mathrm{~L}$ tanks (100 fish tank ${ }^{-1}$ ) in a semi-static system. Tanks contained dechlorinated well water (200 L tank $\left.\mathrm{k}^{-1}\right)$ which was constantly aerated and renewed every second day. Water quality parameters during acclimation, as well as throughout the experimental period, were: $20.4 \pm 0.01{ }^{\circ} \mathrm{C}$ and dissolved oxygen 8.0 $\pm 0.16 \mathrm{mg} \mathrm{L}^{-1}$ (YSI oxygen meter, Model Y5512), $\mathrm{pH}$ $6.9 \pm 0.1$ (DMPH-2 pH meter, Digimed), total ammonia levels $2.05 \pm 0.17 \mathrm{mg} \mathrm{L}^{-1}$ (Verdouw et al., 1978) and unionized ammonia $0.02 \pm 0.0 \mathrm{mg} \mathrm{L}^{-1}$ (Colt, 2002). Fish were fed once a day with a commercial feed containing $28 \%$ crude protein (Supra ${ }^{\circledR}$, Brazil), which was with drawn 24 $\mathrm{h}$ before the commencement of the trials. Experimental protocol was approved by the Ethics Committee on Animal Experimentation of the UFSM (registration no.074,2014).

Anesthesia induction and recovery. EOs were dissolved in $95 \%$ ethanol $(1: 10)$ before addition to the test water. For the evaluation of the anesthetic activity, fish were individually exposed to ethanol (at the highest concentration used to dilute the oils) alone or one of the following EO concentrations: 50, 100, 200 and $300 \mu \mathrm{L} \mathrm{L}^{-1}$ EOC, and 50, 100, 200, 300, 400 and $500 \mu \mathrm{L} \mathrm{L}^{-1}$ EOO (n=9 each concentration). These concentrations were based in pilot studies. Trials were performed in $2 \mathrm{~L}$ aquaria (staticsystem) filled up $1 \mathrm{~L}$ of their capacity with the same water used for acclimation, under constant aeration. Induction of anesthesia was evaluated according to an adaptation of the 
stages described in Small (2003): sedation (partial loss of equilibrium and low reaction to the movement of a glass rod in water) and anesthesia (total loss of equilibrium and no reaction to caudal peduncle pressure). Immediately after anesthesia induction, fish were transferred to similar $2 \mathrm{~L}$ aquaria containing pure water in order to recover from anesthesia. Those which did not reach the anesthesia stage were exposed to EO for $30 \mathrm{~min}$ and then transferred to recovery aquaria. Recovery was completed when the animals restored normal swimming behavior and responsiveness to the movement of a glass rod in water. Once recovered, fish were allocated in $40 \mathrm{~L}$ aquaria and monitored for $48 \mathrm{~h}$ so that any signs of atypical behavior, disease or mortality could be detected.

Ventilatory rate. For the evaluation of the ventilatory rate (VR), fish were exposed to water or ethanol alone (at the highest concentration used to dilute the oils) or one of the following EO concentrations for both oils: 10, 25, 50 and $100 \mu \mathrm{L} \mathrm{L}^{-1}(\mathrm{n}=9$, each fish in a separate aquarium). The EO concentrations used were below those that led to loss of equilibrium in the anesthesia induction tests. Tests were done in $2 \mathrm{~L}$ aquaria under the same environmental conditions as described for anesthesia. Opercular movements were counted along $20 \mathrm{~s}$ at a time, in six distinct time points: $0,0.5,1,2,4$ and $8 \mathrm{~h}$ after fish were transferred to the smaller trial aquaria and maintained in such restricted space. Once the procedure was completed, fish were placed in $40 \mathrm{~L}$ tanks and monitored for $48 \mathrm{~h}$.

Ion fluxes. Levels of $\mathrm{Na}^{+}, \mathrm{K}^{+}$and $\mathrm{Cl}^{-}$were analyzed in the water used to perform the VR trials. Water samples (5 $\mathrm{mL}$ ) were collected from the aquaria just after assessing the VR to avoid stimulation at two different times: 0 and $8 \mathrm{~h}$. Levels of $\mathrm{Na}^{+}$and $\mathrm{K}^{+}$were measured with a flame spectrophotometer B262 (Micronal, São Paulo, Brazil), and the levels of $\mathrm{Cl}^{-}$were analyzed according to Zall et al. (1956). Standard solutions were prepared with analytical grade chemicals dissolved in deionized water, and standard curves were made for each ion to be tested for five different concentrations. Net ion fluxes were calculated based on the following equation: Jnet $=V\left(\left[\right.\right.$ ion $_{1}-\left[\right.$ ion $\left._{2}\right) \times(M x$ $t^{-1}$, where $\left[\right.$ ion $\left._{1}\right]$ and $\left[\right.$ ion $\left._{2}\right]$ are the ion concentrations in the water before and at the end of the experimental period, respectively. $V$ is the water volume (in L), $M$ is the mass of the fish (in $\mathrm{kg}$ ) and $t$ is the duration of the exposure (in h).

Statistical analysis. Homogeneity of variances between treatments was tested with a Levene's test. Data from ion fluxes were parametric and one-way ANOVA and a Tukey's test were applied. Data from anesthesia induction and recovery were non-parametric and assessed by Kruskal-Wallis test followed by a Dunn's test. Data from ventilatory rates for each EO were also non-parametric and were compared by Scherer-Ray-Hare extension of the Kruskal-Wallis test followed by Nemenyi test (time
$\mathrm{X}$ concentration). Statistica software 7.0 was used. Differences were considered significant at $p<0.05$. Data are presented as the mean \pm SEM.

\section{Results}

Major compounds identified for EOC were linalool $(33.41 \%), \delta$-cadinol $(10.93 \%)$ and valencene $(4.12 \%)$ and for EOO terpinen-4-ol (20.44\%), cis-terpinene, (13.14\%), cis-terpineol (12.67\%), 2-carene (7.67\%) and sabinene (6.96\%). No fish died during the course of the anesthesia experiment or over the 48 -h post-tests monitoring period. Neither EO induced sedation at $50 \mu \mathrm{L} \mathrm{L}^{-1}$. Ethanol did not show any sedative or anesthetic effect on fish. Fish exposed to $100 \mu \mathrm{L} \mathrm{L}^{-1}$ EOC only reached sedation, while those subjected to 200 and $300 \mu \mathrm{L} \mathrm{L}^{-1}$ were anesthetized (Fig. 1a). Likewise, $100 \mu \mathrm{L} \mathrm{L}^{-1}$ EOO only induced fish up to the sedation stage, whereas 200, 300, 400 and $500 \mu \mathrm{L}$ $\mathrm{L}^{-1}$ EOO produced anesthesia (Fig. 1b). Induction time decreased as the concentration of both EOs was raised (EOC $p=0.01$; EOO $p=0.02$ ). In the case of EOC, recovery time was lengthier as the concentration increased (EOC $p=0.01$; EOO $p=0.04$ ), but there was no clear relationship between EOO concentration and the time fish took to recover.

Ventilatory rate of all groups decreased as time went by $(p<0.05)$. Ethanol group presented lower ventilatory rate than control group at $4 \mathrm{~h}$ of exposure $(p=0.001)$. A lower VR was observed in fish exposed to $100 \mu \mathrm{L} \mathrm{L}^{-1} \mathrm{EOC}$ than in control and ethanol groups up to $1 \mathrm{~h}(p=0.001)$. There was $100 \%$ mortality in the referred group within 2 $\mathrm{h}$ of exposure. No statistically significant differences were observed for VR between groups exposed to lower EOC concentrations and control and ethanol groups $(p>0.05)$, except in fish exposed to $25 \mu \mathrm{L} \mathrm{L}^{-1}$ EOC for $2 \mathrm{~h}$ compared to control group $(p>0.001)$. Overall, a lower VR was observed in fish exposed to $100 \mu \mathrm{L} \mathrm{L}^{-1} \mathrm{EOO}$ than in control and ethanol groups throughout the $8 \mathrm{~h}$ of experiment $(p>0.001)$. Fish exposed to $10 \mu \mathrm{L} \mathrm{L}^{-1}$ EOO presented lower VR than control group after $2 \mathrm{~h}(p=0.001)$ and 25 and 50 $\mu \mathrm{L} \mathrm{L}^{-1}$ EOO after $1-2 \mathrm{~h}(p=0.001)$ of exposure (Tab. 1). There was no post-testing mortality in the remaining experimental groups.

When $10 \mu \mathrm{L} \mathrm{L}^{-1} \mathrm{EOC}$ was added to the test water, $R$. quelen presented a greater $\mathrm{Na}^{+}$loss compared to ethanol group ( $p=0.04)$. On the other hand, there was a reduction in net $\mathrm{Na}^{+}$efflux in fish subjected to 25 and $50 \mu \mathrm{L} \mathrm{L}^{-1} \mathrm{EOC}$ $(\mathrm{p}=0.005), \mathrm{K}^{+}$efflux at 10 and $50 \mu \mathrm{L} \mathrm{L}^{-1}$ EOC compared to control and ethanol groups $(p=0.01)$, as well as a reduction in net $\mathrm{Cl}^{-}$efflux at all EOC concentrations in comparison with control group ( $p=0.03$ ) (Fig. 2a). Exposure of $R$. quelen to $100 \mu \mathrm{L} \mathrm{L}^{-1} \mathrm{EOO}$ decreased net $\mathrm{Na}^{+}$and $\mathrm{K}^{+}$loss in comparison with control group $\left(\mathrm{Na}^{+} p=0.01 ; \mathrm{K}^{+} p=0.03\right)$. The net $\mathrm{Cl}^{-}$efflux increased at $25 \mu \mathrm{L} \mathrm{L}^{-1}$ EOO compared to ethanol and control groups $(p=0.005)$ and at $100 \mu \mathrm{L} \mathrm{L}^{-1}$ EOO compared to control group ( $p=0.005)$ (Fig. $2 b)$. 

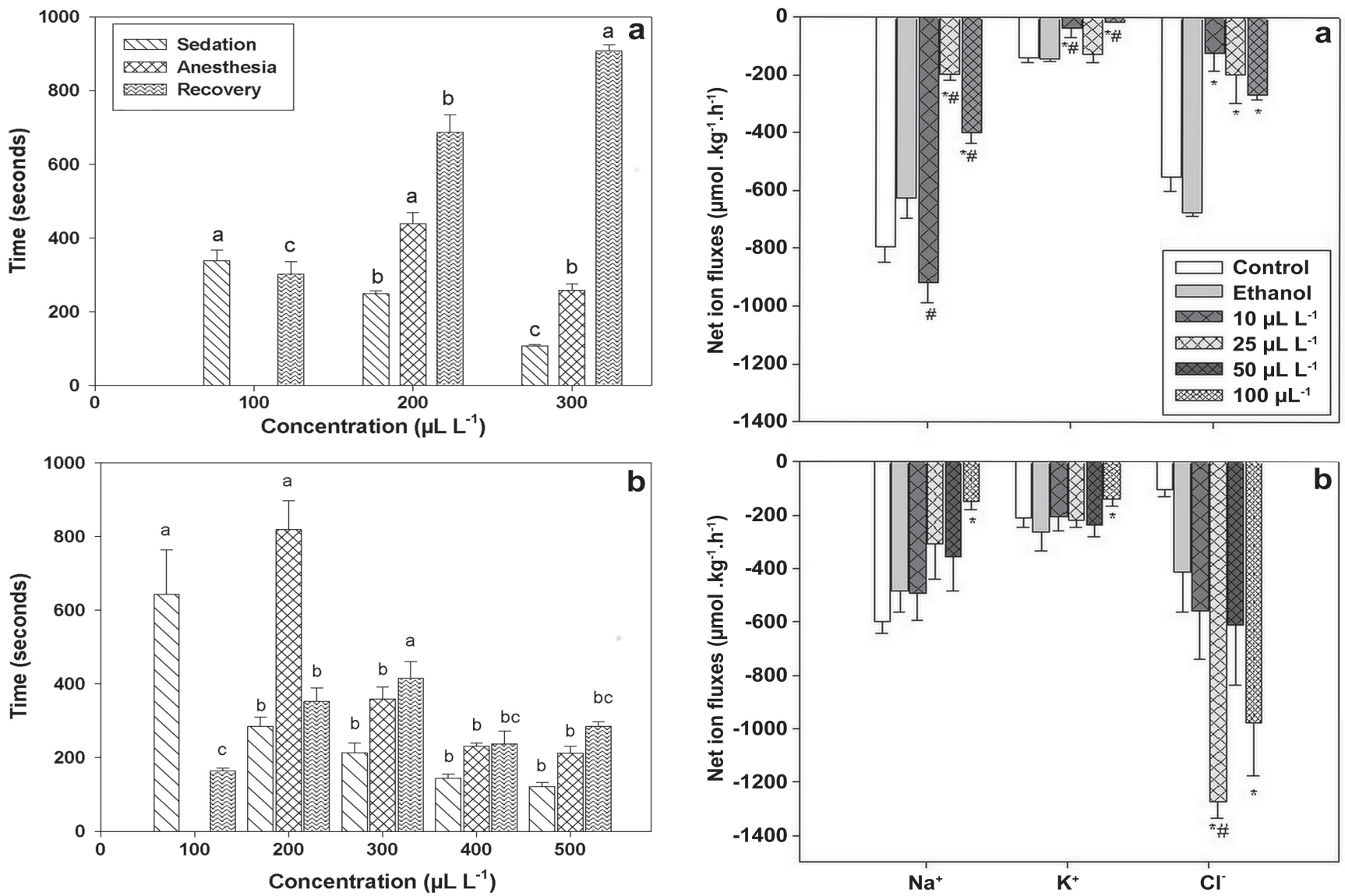

Fig. 1. Time required for induction and recovery from anesthesia in Rhamdia quelen exposed to the essential oil of a. Cunila galioides and b. Origanum majorana. Statistics was performed by one-way ANOVA followed by Tukey's test to assess sedation and anesthesia induction times. For recovery (nonparametric data) was performed Kruskal-Wallis test; $\mathrm{n}=9 ; p<0.05$. Results are expressed as the mean $\pm \mathrm{SEM}$. Different letters indicate statistical difference between concentrations measured in the same stage.

Fig. 2. Effect of exposure for $8 \mathrm{~h}$ to essential oils of a. Cunila galioides and b. Origanum majorana on net $\mathrm{Na}^{+}, \mathrm{K}^{+}$and $\mathrm{Cl}^{-}$ fluxes in Rhamdia quelen. Statistics was performed through oneway ANOVA followed by Tukey test; $\mathrm{n}=9 ; p<0.05$. Results are expressed as the mean \pm SEM. $(*)$ indicates significant difference from control group; (\#) indicates significant difference from ethanol group. There are no data for $100 \mu \mathrm{L} \mathrm{L}^{-1} \mathrm{EOC}$ because all fish died within $2 \mathrm{~h}$ of exposure.

Tab. 1. Effect of the essential oil of Cunila galioides (EOC) and Origanum majorana (EOO) on ventilatory rate in Rhamdia quelen. Statistics was performed through the Scherer-Ray-Hare extension of the Kruskal-Wallis test followed by the Nemenyi test; $\mathrm{n}=9 ; p<0.05$. Results are expressed as the mean \pm SEM. The fish exposed to $100 \mu \mathrm{L} \mathrm{L}^{-1} \mathrm{EOC}$ died within $2 \mathrm{~h}$ of exposure. Lowercase letters indicate significant difference between times in the same group; capital letters indicate significant difference between groups at the same time.

\begin{tabular}{|c|c|c|c|c|c|c|}
\hline \multirow{2}{*}{ Time (hours) } & \multicolumn{6}{|c|}{ Ventilatory rate (beats $\mathrm{min}^{-1}$ ) } \\
\hline & Control & Ethanol & $10 \mu \mathrm{L} \mathrm{L}^{-1}$ & $25 \mu \mathrm{L} \mathrm{L}^{-1}$ & $50 \mu \mathrm{L} \mathrm{L}^{-1}$ & $100 \mu \mathrm{L} \mathrm{L}^{-1}$ \\
\hline \multicolumn{7}{|l|}{ EOC } \\
\hline 0.0 & $36.2 \pm 1.4^{\mathrm{Aa}}$ & $31.6 \pm 0.7^{\mathrm{Aa}}$ & $40.7 \pm 1.4^{\mathrm{Aa}}$ & $37.1 \pm 0.5^{\mathrm{Aa}}$ & $31.9 \pm 0.6^{\mathrm{Aa}}$ & $18.8 \pm 0.6^{\mathrm{Ba}}$ \\
\hline 0.5 & $36.5 \pm 0.5^{\mathrm{Aa}}$ & $26.2 \pm 1.2^{\mathrm{Aab}}$ & $25.9 \pm 0.6^{\mathrm{Ab}}$ & $24.4 \pm 1.5^{\mathrm{Ab}}$ & $27.0 \pm 0.6^{\mathrm{Aa}}$ & $9.1 \pm 0.7^{\mathrm{Ba}}$ \\
\hline 1 & $20.5 \pm 0.5^{\mathrm{Ab}}$ & $18.7 \pm 1.0^{\mathrm{Abc}}$ & $25.1 \pm 1.2^{\mathrm{Ab}}$ & $21.1 \pm 0.2^{\mathrm{Ab}}$ & $19.4 \pm 0.7^{\mathrm{Ab}}$ & $5.1 \pm 0.1^{\mathrm{Ba}}$ \\
\hline 2 & $24.0 \pm 0.5^{\mathrm{Ab}}$ & $20.3 \pm 0.7^{\mathrm{Abc}}$ & $20.1 \pm 0.2^{\mathrm{ABb}}$ & $16.2 \pm 0.3^{\mathrm{Bbc}}$ & $19.2 \pm 0.3^{\mathrm{ABb}}$ & - \\
\hline 4 & $24.2 \pm 1.3^{\mathrm{Ab}}$ & $16.1 \pm 0.5^{\mathrm{Bc}}$ & $21.4 \pm 0.8^{\mathrm{ABb}}$ & $18.1 \pm 0.4^{\mathrm{ABbc}}$ & $18.8 \pm 0.6^{\mathrm{ABb}}$ & - \\
\hline 8 & $14.5 \pm 0.8^{\mathrm{Ac}}$ & $16.0 \pm 0.7^{\mathrm{Ac}}$ & $18.5 \pm 1.3^{\mathrm{Ab}}$ & $14.5 \pm 0.8^{\mathrm{Ac}}$ & $12.8 \pm 0.6^{\mathrm{A}}$ & - \\
\hline \multicolumn{7}{|l|}{$\mathrm{EOO}$} \\
\hline 0.0 & $34.4 \pm 2.1^{\mathrm{Aa}}$ & $32.3 \pm 1.2^{\mathrm{Aa}}$ & $44.0 \pm 1.3^{\mathrm{Aa}}$ & $39.3 \pm 0.3^{\mathrm{Aa}}$ & $32.3 \pm 0.9^{\mathrm{Aa}}$ & $13.6 \pm 1.0^{\mathrm{Ba}}$ \\
\hline 0.5 & $36.0 \pm 0.8^{\mathrm{Aa}}$ & $26.2 \pm 2.1^{\mathrm{Ab}}$ & $26.3 \pm 0.8^{\mathrm{Aa}}$ & $24.3 \pm 0.8^{\mathrm{Aa}}$ & $27.3 \pm 1.6^{\mathrm{Ab}}$ & $13.7 \pm 0.8^{\mathrm{Ba}}$ \\
\hline 1 & $38.3 \pm 0.2^{\mathrm{Aa}}$ & $18.7 \pm 1.8^{\mathrm{ABb}}$ & $27.0 \pm 0.3^{\mathrm{Aa}}$ & $21.3 \pm 0.3^{\mathrm{Ba}}$ & $19.0 \pm 1.5^{\mathrm{Bb}}$ & $12.9 \pm 0.3^{\mathrm{Cb}}$ \\
\hline 2 & $35.3 \pm 0.7^{\mathrm{Aa}}$ & $20.0 \pm 1.2^{\mathrm{ABb}}$ & $19.3 \pm 0.3^{\mathrm{BCb}}$ & $15.00 \pm 0.6^{\mathrm{Ca}}$ & $19.7 \pm 0.4^{\mathrm{BCa}}$ & $12.8 \pm 0.3^{\mathrm{Db}}$ \\
\hline 4 & $25.7 \pm 2.2^{\mathrm{Ab}}$ & $15.9 \pm 0.9^{\mathrm{Bb}}$ & $20.7 \pm 1.4^{\mathrm{Ab}}$ & $19.0 \pm 0.8^{\mathrm{Aa}}$ & $18.7 \pm 0.9^{\mathrm{Ab}}$ & $10.7 \pm 0.8^{\mathrm{Bb}}$ \\
\hline 8 & $14.1 \pm 1.5^{\mathrm{ABb}}$ & $16.5 \pm 1.4^{\mathrm{ABb}}$ & $18.7 \pm 2.4^{\mathrm{Ab}}$ & $14.7 \pm 1.3^{\mathrm{BCb}}$ & $13.3 \pm 0.9^{\mathrm{BCb}}$ & $10.8 \pm 0.6^{\mathrm{Cb}}$ \\
\hline
\end{tabular}




\section{Discussion}

Essential oils are highly complex mixtures of components which are classified according to their percentages in major (20-95\%), secondary (1-20\%) and trace constituents (below 1\%) (Bakkali et al., 2008). Terpinen-4-ol was identified as the major compound by chromatographic analysis of EOO, corroborating previous studies that identified this terpenoid in similar percentages (Vági et al., 2005). Chromatographic analysis of the EOC identified linalool as its major constituent, diverging from prior reports which described its occurrence in a much lower percentage (Fracaro et al., 2002; Echeverrigaray et al., 2003). Such variation in the chemical composition of the EOs is rather common, since it is related to the chemotypes, i.e. chemical races in the producing plant species (Gobbo-Neto, Lopes, 2007), vegetative stage and pedological characteristics of the place of collection (soil properties, irrigation, micro-nutrients) (Martins et al., 2006).

In line with previous findings with EOs of $L$. alba (Cunha et al., 2010), N. megapotamica (Tondolo et al., 2013) and A. triphylla (Gressler et al., 2014; Parodi et al., 2014), increasing concentrations of both EOC and EOO proportionally decreased sedation and anesthesia induction time. As stated by Marking, Meyer (1985), an ideal fish anesthetic should induce anaesthesia in less than $3 \mathrm{~min}$, and recovery should occur in $5 \mathrm{~min}$. In the present study, the two highest concentrations of EOO tested, 400 and $500 \mu \mathrm{L} \mathrm{L}^{-1}$, promoted anesthesia in less than $4 \mathrm{~min}$, which approaches this recommendation, and recovery within the preconized time. Recovery from EOO anesthesia did not become proportionally longer as concentration increased, and was never higher than $7 \mathrm{~min}$. As for the EOC, anesthesia induction took over $4 \mathrm{~min}$, and recovery in general was quite lengthy, above $10 \mathrm{~min}$, and increased as the concentration was raised.

This discrepancy in the pharmacokinetics of the EOs may be explained by their different lipophilic components. Moreover, the EOs are mixtures whose components may have a different level of lipid solubility, thus diffusion rate across soluble membranes at the CNS is distinct. Different degrees of affinity to adipose tissue may also influence elimination of these compounds through the gills and can prolong recovery (Zahl et al., 2012).

Although pharmacological activities observed for EO can be determined by their major components, they are often derived from complex interactions between different substances involving additive, synergistic, potentiation and or even antagonic effects (Efferth, Koch, 2011; Benovit et al., 2015). Despite the difference in induction and recovery times between the EOs, both natural products triggered anesthetic action, which may be correlated to the presence of specific chemical compounds. In the case of EOC, linalool is the main compound, which has been reported as sedative and anesthetic for $R$. quelen (Heldwein et al., 2014). EO of linalool chemotype $L$. alba has similarly induced anesthesia in R. quelen (Cunha et al, 2010; Toni et al., 2014) and in L.vannamei (Parodi et al., 2012).
As regards the EOO, one of its main constituents is terpinen-4-ol, which has presented sedative effect at low concentrations (3-10 $\left.\mathrm{mg} \mathrm{L}^{-1}\right)$ in $R$. quelen (Silva et al., 2013a). Another major compound of EOO, cis-terpineol, has

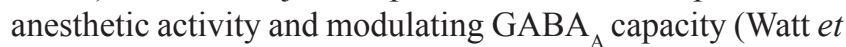
al., 2008), but so far no anesthetic activity was related to the other compounds found in EOC and EOO.

VR is a non-invasive method which indicates physiological changes in the respiratory system triggered by acute stressors, e.g., handling (Barreto, Volpato, 2004) and substances such as anesthetics (Becker et al., 2016). A commonly seen feature when animals are manipulated, transferred to confined spaces or come into contact with anesthetics dispersed in the water is hyperventilation, since these factors induce an increase in oxygen uptake at first (Summerfelt, Smith, 1990). Probably the transference of $R$. quelen to the aquaria to measure VR and net ion fluxes caused stress, which led to the high VR observed. As time went by, VR progressively reduced in control fish, as observed in previous studies with this species (Becker et al., 2012; Toni et al., 2015). The effect usually described for anesthetics is reduction in oxygen uptake and metabolic rate (Keene et al., 1998; Becker et al., 2012; Toni et al., 2015; Cupp et al., 2016). In the present study, $100 \mu \mathrm{L} \mathrm{L}^{-1} \mathrm{EOC}$ progressively reduced VR (and probably oxygen uptake) with time and caused the death of all fish between the $1 \mathrm{~h}$ and the $2 \mathrm{~h}$ assessments. On the other hand, $100 \mu \mathrm{L} \mathrm{L}^{-1} \mathrm{EOO}$ also lowered VR at the moment of exposure (time zero), but did not reduced it further, avoiding $R$. quelen mortality throughout the tests. Other EOO concentrations (25 and 50 $\mu \mathrm{L} \mathrm{L}^{-1}$ ) only induced VR reductions within 1-2 $\mathrm{h}$ compared to control and ethanol groups.

Although natural products have been explored as an alternative to the synthetic chemicals, they may be toxic to fish if exposure protocols are not adequate, e.g., incorrect concentration, and time exposure, or due to the presence of a particular component. A study with Nile tilapia (Oreochromis niloticus), for instance, has reported high toxicity of allicin, which is the main constituent of the garlic EO (Hussein et al., 2013). In the Brazilian flounder (Paralichthys orbignyanus), the EO of Aloysia gratissima elicited paralysis and mortality during anesthesia (Benovit et al., 2012). Other undesirable effects have been reported in fish exposed to natural anesthetics: increased lactate content with $N$. megapotamica, L. alba and H. ringens EOs (Tondolo et al., 2013; Toni et al., 2014), elevated glucose levels with mentol (Simões, Gomes, 2009; Sanchez et al., 2014), increased plasma cortisol with clove oil (Bressler, Ron, 2004; Weber et al., 2011) and increased hematocrit and disturbances of hydromineral balance with A. triphylla EO (Gressler et al., 2014). Thus, as any other product used in fish farming, safety and efficacy of EOs should be carefully investigated for individuals of a given species.

Physiological changes which take place when homeostasis is disturbed are initially an effect of the rapid increase in plasma catecholamines levels post-stress. 
At a later stage, the rise in plasma cortisol levels is also accountable for inducing organic adjustments (Barton, 2002; Pankhurst, 2011). Concentrations of plasma ions are among these changes, and several works correlate the increase in $R$. quelen ion efflux with exposure to stressors (Becker et al., 2012, 2016; Parodi et al., 2014; Zeppenfeld et al., 2014; Salbego et al., 2015). Variations in plasma ion levels are a result of the exchange between the internal and the external milieu (Dang et al., 2000; Barton, 2002; Pankhurst, 2011). Upon stress, cathecolamines trigger an increase in gill blood flow and boosts oxygen uptake through the lamellar surface (Wendelaar Bonga, 1997). Consequently, osmoregulation is compromised, since increased water intake in order to absorb more oxygen is accompanied by diffusive ion loss (Gonzalez, McDonald, 1994). Though not high enough to induce sedation in fish and to promote only transient reductions of VR, concentrations of $25-50 \mu \mathrm{L} \mathrm{L}^{-1}$ EOC were able to confer $R$. quelen some protection against the ionic loss seen for the control and ethanol groups induced by capture, transfer and confinement stress. The concentrations of $10 \mu \mathrm{L}$ $\mathrm{L}^{-1} \mathrm{EOC}$ and $100 \mu \mathrm{L} \mathrm{L}^{-1} \mathrm{EOO}$ also reduced net loss of two of the studied ions, but increased $\mathrm{Na}^{+}$and $\mathrm{Cl}^{-}$loss, respectively. The effect of both EOs on some net ion fluxes (EOC - $\mathrm{Na}^{+}$ and $\mathrm{K}^{+}, \mathrm{EOO}-\mathrm{Cl}^{-}$) was not concentration-related. Other plant extratives have also proven to be efficient in reducing ion effluxes in R. quelen, e.g., EOs of L. alba (Becker et al., 2012, 2016), A. triphylla (Parodi et al., 2014; Zeppenfeld et al., 2014) and Ocimum gratissimum (Silva et al., 2015) and the methanolic extract of Condalia buxifolia (Salbego et al., 2015). In spite of reducing ion fluxes, the effect of EOs of $L$. alba (Becker et al., 2012, 2016) and A. triphylla (Parodi et $a l ., 2014$ ) also was not concentration-related for some ions.

Both evaluated EOs displayed a CNS depressant activity when tested at $\geq 100 \mu \mathrm{L} \mathrm{L}^{-1}$, but anesthesia stage was only effectively achieved in $R$. quelen with $\geq 400 \mu \mathrm{L} \mathrm{L}^{-1}$ EOO, considering induction times. EOC had a mild effect on reducing $\mathrm{VR}$, except $100 \mu \mathrm{L} \mathrm{L}^{-1}$, which induced $100 \%$ mortality of the fish exposed for more than $1 \mathrm{~h}$. However, $25-50 \mu \mathrm{L} \mathrm{L}^{-1}$ decreased ion loss. EOO at $100 \mu \mathrm{L} \mathrm{L}^{-1}$ reduced $\mathrm{VR}$ and $\mathrm{Na}^{+}$and $\mathrm{K}^{+}$loss, but increased $\mathrm{Cl}^{-}$loss. In view of the present findings, EOC at $200-300 \mu \mathrm{L} \mathrm{L}^{-1}$ and EOO at $400-500 \mu \mathrm{L} \mathrm{L}^{-1}$ present the potential to promote fast anesthesia in $R$. quelen. Lower concentrations of these EOs (EOC - 25-50 $\mu \mathrm{L} \mathrm{L}^{-1}$, EOO - $100 \mu \mathrm{L} \mathrm{L}^{-1}$ ) seem promising for further studies regarding fish transport due to their effects on VR and or net ion fluxes.

\section{Acknowledgments}

This study was supported by National Council for Scientific and Technological Development,CNPq (\#454447; 2014-0) and Ministry of Fisheries and Aquaculture, FINEP (\#01.12.0130.00). B. Baldisserotto and B. M. Heinzmann are grateful to $\mathrm{CNPq}$ for research fellowship. Authors also thank Coordination for the Improvement of Higher Education Personnel (CAPES) for graduate fellowships to J. A. Cunha, J. Salbego and C. G. Pinheiro, Rio Grande do Sul Research Support Foundation (FAPERGS) for graduate fellowship to L. T. Gressler and $\mathrm{CNPq}$ for undergraduate students fellowships C. A. Scheeren and G. J. Bandeira. Authors are especially thankful to Edione Dornelles for providing the EOO (Vimontti ${ }^{\circledR}$ ), and to B. Schindler and M. Figueira for helping to collect $C$. galioides plant material.

\section{References}

Adams RP. Identification of essential oil components by gas chromatography/quadrupole mass spectroscopy. 3rd ed. Illinois: Allured Publishing Corporation; 2001.

Baldisserotto B. Piscicultura continental no Rio Grande do Sul: situação atual, problemas e perspectivas para o futuro. Cienc Rural. 2009; 39(1):291-99.

Bakkali F, Averbeck S, Averbeck D, Idaomar M. Biological effects of essential oils - A review. Food Chem Toxicol. 2008; 46:446-75.

Barreto RE, Volpato GL. Caution for using ventilatory frequency as an indicator of stress in fish. Behav Processes. 2004; 66:43-51.

Barton BA, Peter RE, Paulencu CR. Plasma cortisol levels of fingerling rainbow trout (Salmo gairdneri) at rest, and subjected to handling confinement, transport and stocking. Can J Fish Aquat Sci. 1980; 37:805-11.

Barton BA. Stress in fishes: A diversity of responses with particular reference to changes in circulating corticosteroids. Integr Comp Biol. 2002; 42:517-25.

Becker AG, Parodi TV, Heldwein CG, Zeppenfeld CC, Heinzmann BM, Baldisserotto B. Transportation of silver catfish, Rhamdia quelen, in water with eugenol and the essential oil of Lippia alba. Fish Physiol Biochem. 2012; 38:789-96.

Becker AG, Parodi TV, Zeppenfeld CC, Salbego J, Cunha MA, Heldwein CG, Loro VL, Heinzmann BM, Baldisserotto B. Presedation and transport of Rhamdia quelen in water containing essential oil of Lippia alba: metabolic and physiological responses. Fish Physiol Biochem. 2016; 42(1):73-81.

Benovit SC, Silva LL, Salbego J, Loro VL, Mallmann CA, Baldisserotto B, Flores EM, Heinzmann BM. Anesthetic activity and bio-guided fractionation of the essential oil of Aloysia gratissima (Gillies \& Hook.) Tronc. in silver catfish Rhamdia quelen. An Acad Bras Ciênc. 2015; 87(3):1675-89.

Benovit SC, Gressler LT, Silva LL, Garcia LO, Okamoto MH, Pedron JS, Sampaio LA, Rodrigues RV, Heinzmann BM, Baldisserotto B. Anesthesia and transport of Brazilian flounder, Paralichthys orbignyanus, with essential oils of Aloysia gratissima and Ocimum gratissimum. J World Aquac Soc. 2012; 43(6):896-900.

Bolasina SN. Cortisol and hematological response in Brazilian codling, Urophycis brasiliensis (Pisces, Phycidae) subjected to anesthetic treatment. Aquacult Int. 2006; 14: 569-75.

Brasil, Ministério da Pesca e Aquicultura (MPA). Aquicultura potencial brasileiro e produção. 2014a. [cited 12 Oct 2015]. Available from: http://www.mpa.gov.br/aquicultura/potencialbrasileiro

Brasil, Ministério da Pesca e da Aquicultura. $1^{\circ}$ Anuário brasileiro da pesca e Aquicultura. Florianópolis: Associação Cultural e Educacional Brasil. 2014b. [cited 13 Oct 2015]. Available from: http://formsus.datasus.gov.br/ novoimgarq/16061/2489520_218117.pdf 
Bressler K, Ron B. Effect of anesthetics on stress and the innate immune system of gilthead seabream (Sparus aurata). The Israeli Journal of Aquaculture = Bamidgeh. 2004; 56(1):5-13.

Colt J. List of spreadsheets prepared as a complement. In: Wedemeyer GA, editor. Fish hatchery management. 2nd ed. CITY:American Fisheries Society; 2002. Available from: http://www.fisheries. org/afs/hatchery.html

Cunha MA, Barros FMC, Garcia LO, Veeck APL, Heinzmann BM, Loro VL, Emanuelli T, Baldisserotto B. Essential oil of Lippia alba: A new anesthetic for silver catfish, Rhamdia quelen. Aquaculture. 2010; 306:403-06.

Cupp AR, Hartleb CF, Fredricks KT, Gaikowski MP. Effectiveness of eugenol sedation to reduce the metabolic rates of cool and warm water fish at high loading densities. Aquac Res. 2016; 47:234-42.

Dang Z, Balm PHM, Flik G, Wendelaar Bonga SE, Lock RAC. Cortisol increases $\mathrm{Na}+/ \mathrm{K}+$-ATPase density in plasma membranes of gill chloride cells in the freshwater tilapia Oreochromis mossambicus. J Exp Biol. 2000; 203:2349-55.

Deshmane DN, Gadgoli CH, Halade GV. 2007. Anticonvulsant effect of Origanum majorana L. Pharmacology online. 2007; 1:64-78.

Echeverrigaray S, Fracaro F, Santos ACA, Paroul N, Wasum R, Serafini LA. Essential oil composition of South Brazilian populations of Cunila galioides and its relation with the geographic distribution. Biochem Syst Ecol. 2003; 31:467-75.

Efferth T, Koch E. Complex interactions between phytochemicals. The multi-target therapeutic concept of phytotherapy. Curr Drug Targets. 2011; 12(1):122-32.

Council of Europe (COE). European Pharmacopoeia. $6^{\text {th }}$ ed. Strassbourg:European Directorate for the Quality of Medicines; 2007.

Fracaro F, Serafini LA, Santos ACA, Paroul N, Echeverrigaray S, Wasum R. Analysis of the essential oil composition of Cunila galioides Benth. J Essent Oil Res. 2002; 14:336-38.

Fratini F, Casella S, Leonardi M, Pisseri F, Ebani VV, Pistelli L, Pistelli L. Antibacterial activity of essential oils, their blends and mixtures of their main constituents against some strains supporting livestock mastitis. Fitoterapia. 2014; 96:1-7.

Gobbo-Neto L, Lopes NP. Plantas medicinais: fatores de influência no conteúdo de metabólitos secundários. Quim Nova. 2007; 30(2):374-81.

Gomes LC, Golombieski JI, Gomes ARC, Baldisserotto B . 2000. Biologia do jundiá Rhamdia quelen (Teleostei, Pimelodidae). Cien Rural. 2000; 30(1):179-85.

Gonzalez RJ, McDonald DG. The relationship between oxygen uptake and ion loss in fish from diverse habitats. J Exp Biol. 1994; 190:95-108.

Gressler LT, Riffel APK, Parodi TV, Saccol EMH, Koakoski G, Costa ST, Pavanato MA, Heinzmann BM, Caron B, Schmidt D, Llesuy SF, Barcellos LJG, Baldisserotto B. Silver catfish Rhamdia quelen immersion anaesthesia with essential oil of Aloysia triphylla (L'Hérit) Britton or tricaine methanesulfonate: effect on stress response and antioxidant status. Aquac Res. 2014; 45:1061-72.

Heldwein CG, Silva LL, Gai EZ, Roman C, Parodi TV, Bürger ME, Baldisserotto B, Flores EM, Heinzmann BM. S-(+)-Linalool from Lippia alba: sedative and anesthetic for silver catfish (Rhamdia quelen). Vet Anaesth Analg. 2014; 41:621-29.

Hussein MMAH, Hassan WH, Moussa IMI. Potential use of allicin (garlic, Allium sativum Linn, essential oil) against fish pathogenic bacteria and its safety for monosex Nile tilapia (Oreochromis niloticus). Int J Food Agric Environ. 2013; 11:696-09.
Jun WJ, Han BK, Yu KW, Kim MS, Chang IS, Kim HY, Cho HY. Antioxidant effects of Origanum majorana L. on superoxide anion radicals. Food Chem. 2001; 75:439-44.

Keene JL, Noakes DLG, Moccia RD, Soto CG. The efficacy of clove oil as an anaesthetic for rainbow trout, Oncorhynchus mykiss (Walbaum). Aquac Res. 1998; 29:89-101.

Marking LL, Meyer FP. 1985. Are better anesthetics needed in fisheries? Fisheries. 1985; 10:2-5.

Martins FT, Santos MH, Polo M, Barbosa LCA. Variação química do óleo essecial de Hyptis suaveolens (L.) Poit., sob condições de cultivo. Quim Nova. 2006; 29(6):1203-09.

Mossi AJ, Pauletti GF, Rota L, Echeverrigaray S, Barros IBI, Oliveira JV, Paroul NI, Cansian RL. Effect of different liming levels on the biomass production and essential oil extraction yield of Cunila galioides Benth. Braz J Biol. 2012; 72(4):787-93.

National Institute of Standards and Technology - NIST. PC version of the NIST/EPA/NIH Mass Spectral Database. Gaithersburg: U. S. Department of Commerce. 2010.

Orhan IE, Özçelik B, Kartal M, Kan Y. Antimicrobial and antiviral effects of essential oils from selected Umbelliferae and Labiatae plants and individual essential oil components. Turk J Biol. 2012; 36(3):239-46.

Pankhurst NW. The endocrinology of stress in fish: an environmental perspective. Gen Comp Endocrinol. 2011;170:265-75.

Parodi TV, Cunha MA, Heldwein CG, Souza DM, Martins AC, Garcia LO, Wasielesky W, Monserrat JM, Schmidt D, Caron BO, Heinzmann BM, Baldisserotto B. The anesthetic efficacy of eugenol and the essential oils of Lippia alba and Aloysia triphylla in post-larvae and sub-adults of Litopenaeus vannamei (Crustacea, Penaeidae). Comp Biochem Physiol C Pharmacol Toxicol Endocrinol. 2012; 155(3):462-68.

Parodi TV, Cunha MA, Becker AG, Zeppenfeld CC, Martins DI, Koakoski G, Barcellos LG, Heinzmann BM, Baldisserotto B. Anesthetic activity of the essential oil of Aloysia triphylla and effectiveness in reducing stress during transport of albino and gray strains of silver catfish, Rhamdia quelen. Fish Physiol Biochem. 2014; 40:323-34.

Salbego J, Becker AG, Parodi TV, Zeppenfeld CC, Gonçalves JF, Loro VL, Morsch VMM, Schetinger MRC, Maldaner G, Morel AF, Baldisserotto B. Methanolic extract of Condalia buxifolia added to transport water alters biochemical parameters of the silver catfish Rhamdia quelen. Aquaculture. 2015; 437:46-50.

Sanchez MSS, Rodrigues RA, Nunes AL, Oliveira AMS, Fantini LE, Campos CM. Efeito do mentol e eugenol sobre as respostas fisiológicas do pacu Piaractus mesopotamicus. Semin: Cienc Agrar. 2014; 35(4):2799-808.

Silva LL, Garlet QI, Benovit SC, Dolci G, Mallmann CA, Burger ME, Baldisserotto B, Longhi SJ, Heinzmann BM. Sedative and anesthetic activities of the essential oils of Hyptis mutabilis (Rich.) Briq. and their isolated components in silver catfish (Rhamdia quelen). Braz J Med Biol Res. 2013a; 46:771-79.

Silva LL, Silva DT, Garlet QI, Cunha MA, Mallmann CA, Baldisserotto B, Longhi SJ, Pereira AMS, Heinzmann BM. Anesthetic activity of Brazilian native plants in silver catfish (Rhamdia quelen). Neotrop Ichthyol. 2013b; 11(2):443-51.

Silva LL, Garlet QI, Koakoski G, Oliveira TA, Barcellos LJG, Baldisserotto B, Pereira AMS, Heinzmann BM. Effects of anesthesia with the essential oil of Ocimum gratissimum L. in parameters of fish stress. Rev Bras P1 Med. 2015; 17(2):215-23. 
Silva LL, Parodi TV, Reckziegel P, Garcia VO, Bürger ME, Baldisserotto B, Malmann CM, Pereira AMS, Heinzmann BM. Essential oil of Ocimum gratissimum L.: anesthetic effects, mechanism of action and tolerance in silver catfish, Rhamdia quelen. Aquaculture. 2012; 350-353:91-97.

Simões LN, Gomes LC. Eficácia do mentol como anestésico para juvenis de tilápia-do-nilo (Oreochromis niloticus). Arq Bras Med Vet Zootec. 2009; 61(3):613-20.

Sladky KK, Swanson CR, Stoskopf MK, Loomis MR, Lewbart GA. Comparative efficacy of tricainemethanesulfonate and clove oil for use as anesthetics in red pacu (Piaractus brachypomus). Am J Vet Res. 2001; 62(3):337-42.

Small BC. Anesthetic efficacy of metomidate and comparison of plasma cortisol responses to tricaine methanesulfonate, quinaldine and clove oil anesthetized channel catfish Ictalurus punctatus. Aquaculture. 2003; 218:177-85.

Summerfelt RC, Smith LS. Anesthesia, surgery, and related techniques. In: Schreck CB, Moyle PB, editors. Methods for fish biology. Bethesda: American Fish Society; 1990. p. 213-272.

Tondolo JSM, Amaral LP, Simões LN, Garlet QI, Schindler B, Oliveira TM, Silva BF, Gomes LC, Baldisserotto B, Mallmann CA, Heinzmann BM. Anesthesia and transport of fat snook Centropomus parallelus with the essential oil of Nectandra megapotamica (Spreng.) Mez. Neotrop Ichthyol. 2013; 11(3):667-74.

Toni C, Becker AG, Simões LN, Pinheiro CG, Silva LL, Heinzmann BM, Caron BO, Baldisserotto B. Fish anesthesia: effects of the essential oils of Hesperozygis ringens and Lippia alba on the biochemistry and physiology of silver catfish (Rhamdia quelen). Fish Physiol Biochem. 2014; 40:701-14.

Toni C, Martos-Sitcha JA, Ruiz-Jarabo I, Mancera JM, MartínezRodríguez G, Pinheiro CG, Heinzmann BM, Baldisserotto B. Stress response in silver catfish (Rhamdia quelen) exposed to the essential oil of Hesperozygis ringens. Fish Physiol Biochem. 2015; 41:129-38.

Tserennadmid R, Takó M, Galgóczy L, Papp T, Vágvölgyi C, Gerő L, Krisch J. Antibacterial effect of essential oils and interaction with food components. Cent Eur J Biol. 2010; 5(5):641-48.
Vági E, Simándi B, Suhajda Á, Héthelyic E. Essential oil composition and antimicrobial activity of Origanum majorana L. extracts obtained with ethyl alcohol and supercritical carbon dioxide. Food Res Int. 2005; 38:51-57.

Verdouw H, Van Echteld CJA, Dekkers EMJ. Ammonia determination based on indophenol with sodium salicylate. Water Res. 1978; 12:399-402.

Watt EE, Betts BA, Kotey FO, Humbert DJ, Griffith TN, Kelly EW, Veneskey KC, Gill N, Rowan KC, Jenkins A, Hall AC. Menthol shares general anesthetic activity and sites of action on the $\mathrm{GABA}_{\mathrm{A}}$ receptor with the intravenous agent, propofol. Eur J Pharmacol. 2008; 590(1-3):120-26.

Weber RA, Pérez-Maceira JJ, Peleteiro JB, García-Martín L, Aldegunde M. Effects of acute exposure to 2-phenoxyethanol, clove oil, MS-222, and metomidate on primary and secondary stress responses in Senegalese sole (Solea senegalensis Kaup 1858). Aquaculture. 2011; 321(1-2):108-12.

Wendelaar Bonga SE. The stress response in fish. Physiol Rev. 1997; 77(3):591-625.

Zahl IH, Samuelsen O, Kiessling A. Anaesthesia of farmed fish: implications for welfare. Fish Physiol Biochem. 2012; 38:20118.

Zall DM, Fisher D, Garner MQ. Photometric determination of chlorides in water. Anal Chem Res. 1956; 28:1665-68.

Zeppenfeld CC, Toni C, Becker AG, Miron DS, Parodi TV, Heinzmann BM, Barcellos LJG, Koakoski G, Rosa JGS, Loro VL, Cunha MA, Baldisserotto B. Physiological and biochemical responses of silver catfish, Rhamdia quelen, after transport in water with essential oil of Aloysia triphylla (L'Herit) Britton. Aquaculture. 2014; 418-419:101-07.

Submitted June 30, 2016 Accepted February 7, 2017 by Juan Miguel Mancera 